\title{
Change and continuity in East Asian business systems
}

Link to publication record in Manchester Research Explorer

\section{Citation for published version (APA):}

Whitley, R., Witt, M. (Ed.), \& Redding, G. (Ed.) (2013). Change and continuity in East Asian business systems. In Oxford handbook of asian business systems (pp. 626-657). Oxford University Press.

http://www.worldcat.org/oclc/833046412

\section{Published in:}

Oxford handbook of asian business systems

\section{Citing this paper}

Please note that where the full-text provided on Manchester Research Explorer is the Author Accepted Manuscript or Proof version this may differ from the final Published version. If citing, it is advised that you check and use the publisher's definitive version.

\section{General rights}

Copyright and moral rights for the publications made accessible in the Research Explorer are retained by the authors and/or other copyright owners and it is a condition of accessing publications that users recognise and abide by the legal requirements associated with these rights.

\section{Takedown policy}

If you believe that this document breaches copyright please refer to the University of Manchester's Takedown Procedures [http://man.ac.uk/04Y6Bo] or contact uml.scholarlycommunications@manchester.ac.uk providing relevant details, so we can investigate your claim.

\section{OPEN ACCESS}




\title{
CHANGE AND CONTINUITY IN EAST ASIAN BUSINESS SYSTEMS
}

\author{
RICHARD WHITLEY
}

\section{INTRODUCTION}

THE international success of firms from Japan, and later South Korea, Taiwan, and elsewhere in Pacific-Asia in the 1960 os and 1970 s encouraged considerable academic and journalistic interest in the distinctive features of these companies and the socio-political environment in which they became competitive (e.g. Amsden 1989; Calder 1993; Wade 1990). A central part of the post-war environment in which these firms became successful was the strong 'developmental state' (Johnson 1982; Weiss 2010; Wu 2007) that coordinated and often directed investments and strategic choices in different technologies, industries, and markets. The role of the state in guiding socio-economic development has been crucial in structuring the kind of market economy and dominant firms that became established in Asian societies over the past half-century or so. However, relationships between political elites, senior civil servants in different part of the state bureaucracy, and major economic interest groups have varied greatly between Asian countries and over time, as have state policies towards steering industrialization and later development.

These differences have had significant influence on the prevailing patterns of economic coordination and control, or business systems, dominating Asian economies in the first three decades after 1945 and subsequent changes. Because the state has been so important in structuring the nature of dominant business systems in different national territories, especially in its strong developmental form, the comparative analysis of economic organization has tended to focus on national, rather than intra-national regional or sectoral, similarities and differences.

This was particularly so during the heyday of the Bretton Woods System (BWS) for managing international financial flows and imbalances, when national economies were 
more insulated from each other and governed by predominantly national institutions reflecting the choices of powerful, nationally organized groups. Consequently, many key institutions governing the constitution and behaviour of economic actors, including property-rights regimes and the organization of capital and labour markets, were nationally specific and variable between countries. Hence, the governance of leading companies, their dominant strategic goals and how they pursued these differed considerably between nationally distinct institutional regimes, thus generating different kinds of economic organization at national level. Most of the diverse systems of economic coordination and control established in the post-war period did so within nation states.

However, in practice, the homogenizing impact of national institutions has differed between countries and varied over time. Currently dominant ways of organizing economic activities in any given jurisdiction can be transformed through both internal conflicts and external pressures. In particular, the collapse of the BWS in the early 1970s, subsequent deregulation of many national capital markets, and expansion of the visible hand of managerial coordination and control across national borders through foreign direct investment by multinational companies have arguably reduced national specificities.

The national distinctiveness and homogeneity of post-war Asian business systems are, then, contingent and changeable. It is particularly in countries most successful in pursuing strong developmental policies that we might expect shifts in the dominant forms of economic organization, as successful firms attempt to increase their autonomy, and influential interest groups become more diverse and assertive. This is especially likely where an authoritarian state undergoes substantial democratization, as in South Korea (henceforth Korea) and Taiwan. The very success of these policies in generating or at least strongly contributing to high economic growth and the development of internationally competitive companies is likely to change the conditions that enabled them, as well as changes in the external political environment, reducing the viability of protectionist policies and autarchic economic strategies, as Gray (2011) has emphasized in Taiwan.

In this article, I explore the changing connections between dominant institutions and business systems through a comparative analysis of how significant institutional changes in Japan, Korea, and Taiwan and their environments have been associated with shifts in some characteristics of their nationally dominant business systems. While some changes could be considered complementary in the sense of reinforcing the impact of key institutions on leading firms and market structures, others have had mixed consequences for established patterns of economic organization. Initially, I summarize the characteristics of the East Asian business systems dominating these economies in the high-growth periods in terms of concepts developed previously (Whitley 1992, 1999), before comparing key institutional factors that helped to generate and reproduce them. In the following section I outline major changes in some of these institutional features after the collapse of the BWS and oil-price shocks of 1973 and 1979. In the final section, I consider how these changes seem to have altered the national homogeneity and dominance of these business systems and led to significant shifts in some characteristics. 


\section{Post-War East Asian Business Systems}

In Table 28.1, I contrast the eight major characteristics of the post-war business systems that became established in Japan, Korea, and Taiwan (Fields 1995; Gerlach 1992; Orrù, Biggart, and Hamilton 1997; Shin and Hamilton 2013; Whitley 1992). These summarize the prevalent patterns of coordination and control of economic activities that the strong complementarities of the major national institutions governing economic relationships and actions helped to ensure dominated each national political economy (Whitley 2005).

Considering first the degree of ownership-based coordination and control of economic activities, a major contrast between these three countries concerns the

Table 28.1 Characteristics of dominant post-war business systems in East Asia

\begin{tabular}{|c|c|c|c|}
\hline Dominant Business System Characteristics & Japan & South Korea & Taiwan \\
\hline \multicolumn{4}{|l|}{ Ownership-based coordination and control } \\
\hline Owner-manager relationships & Committed & Direct & Direct \\
\hline $\begin{array}{l}\text { Vertical integration of dominant } \\
\text { private firms }\end{array}$ & Medium & High & Low \\
\hline $\begin{array}{l}\text { Horizontal integration by dominant } \\
\text { firms }\end{array}$ & $\begin{array}{l}\text { Medium, but } \\
\text { mostly in related } \\
\text { industries }\end{array}$ & High & High \\
\hline \multicolumn{4}{|l|}{ Alliance-based coordination and control } \\
\hline Vertical alliance integration & Considerable & Low & $\begin{array}{l}\text { Limited to } \\
\text { short-term } \\
\text { connections except } \\
\text { for centre-satellite } \\
\text { networks in some } \\
\text { industries }\end{array}$ \\
\hline Horizontal alliance integration & Considerable & Low & $\begin{array}{l}\text { Limited to } \\
\text { short-term } \\
\text { partnerships }\end{array}$ \\
\hline Competitor collaboration & Considerable & Low & $\begin{array}{l}\text { Limited, } \\
\text { predominantly } \\
\text { short term }\end{array}$ \\
\hline \multicolumn{4}{|l|}{ Organizational integration and commitment } \\
\hline Employer-employee commitment & $\begin{array}{l}\text { High for male } \\
\text { workers in large } \\
\text { firms }\end{array}$ & $\begin{array}{l}\text { Limited, } \\
\text { except for } \\
\text { college-educated } \\
\text { staff in large } \\
\text { firms }\end{array}$ & Limited \\
\hline $\begin{array}{l}\text { Delegation to, and involvement in } \\
\text { problem-solving of, the bulk of the } \\
\text { regular workforce }\end{array}$ & Considerable & Low & Low \\
\hline
\end{tabular}


involvement and control of investors in the management and strategic direction of dominant firms. As numerous analyses have attested, their role has been much less direct and decisive in Japan than in Korea and Taiwan, where owning families tend to dominate top management positions and decision-making (see, e.g. Aoki and Dore 1994; Fields 1995; Kim 1997; Orrù, Biggart, and Hamilton 1997). In many large Japanese companies, significant shareholdings were often owned by committed financial institutions and friendly members of the same business groups, who functioned more as business partners sharing risks, knowledge, and senior personnel than as strategic decision-makers or remote portfolio investors (Witt 2013a). In contrast, most Korean and Taiwanese companies were established and run as family enterprises dominated by the founding family, even when its own direct shareholding fell below 50 per cent.

The extent to which leading private companies owned their supply chains and integrated forward into distribution and retailing activities also differed considerably. Large Japanese firms sometimes integrated backwards, but usually preferred in the post-war period to hold less than 50 per cent, and often under 30 per cent, of suppliers' shares, to conserve capital outlays and save on personnel costs and commitments. Wholly owned vertical integration in Japan thus tended to be lower than in the USA amongst comparable firms, and considerably less than that common amongst the Korean chaebol, particularly in the heavy and chemical-industry sectors (Kim 1997; Fields 1995). In contrast, most private Taiwanese companies and business groups exhibited relatively limited degrees of vertical integration, especially in more capital-intensive industries, not least because of the state/KMT dominance of the upstream sectors (Hamilton and Kao 1990; Fields 1995; Hsieh 2011; Orrù, Biggart, and Hamilton 1997).

Ownership-based horizontal coordination and control varied considerably, with relatively few Japanese companies operating as highly diversified conglomerates, in contrast to Korea's chaebol, which were highly diversified across unrelated industries (Witt 2013b). Taiwanese family businesses also tended to diversify, especially those forming business groups, although these operated more as sets of related enterprises than wholly owned and centrally managed integrated firms like the chaebol (Fields 1995:66-67).

As the title of Gerlach's (1992) book about the post-war Japanese economy, Alliance Capitalism, suggests, economic coordination through alliances between legally independent firms was a major, if not defining, feature of its dominant business system. Both vertically and horizontally, companies were enmeshed in wide-ranging networks of obligations and mutual assistance, from long-term customer-supplier connections to large ex-zaibatsu inter-market groups tied to large banks, and the often state-encouraged collaborations between competing firms to develop new technologies, manage declining demand in recessions, and deal with foreign competitors (Lincoln and Gerlach 2004). The Korean chaebol, in contrast, adopted a largely adversarial approach to suppliers and preferred to buy innovative SMEs rather than develop long-term obligational links to them. Company alliances have rarely been long lived in Korea.

While Taiwanese family firms often develop partnerships for new ventures, these tend to be fairly narrowly focused on particular activities and based on personal commitments rather than long-term organizational alliances (Fields 1995, 2012). Coordination 
through inter-firm networks may have been greater in Taiwan than Korea up to the 1980s, but partnerships were more changeable and project specific than in Japan (Lee and Hsiao 2013). As Numazaki suggests (2000:159), 'Chinese partnership tends to be temporary in nature. This implies the temporary nature of family trade... a Chinese partnership is a coalition of autonomous entrepreneurs. Economic activities, then, are quite highly coordinated through networks between firms in Japan and Taiwan, but these networks are more specific, changeable, and tied to personal relationships in Taiwan than in Japan.

Patterns of authoritative coordination and control of work activities also varied significantly between major firms in these countries. While the popular view of Japan's lifetime employment may have been overstated, the extent of mutual dependence and long-term commitments between employers and regular-usually male-employees in larger companies was clearly considerable, and often included manual workers in a process described as 'white-collarization' (Dore 1973; Koike 1987). Even smaller firms recognized the importance of maintaining skilled-worker commitment to organizational success, as in the Sakaki township machine-tool industry (Friedman 1988).

In contrast, employment commitments were much weaker in most Korean and Taiwanese enterprises, particularly for manual workers, although college-educated chaebol employees could reasonably expect long-term careers in these fast-growing conglomerates (Bae 1987; Janelli 1993; Kim 1992). Such expectations tended to be limited in Taiwan, not least because of the common preference for running one's own business on what Shieh (1992) has termed 'Boss Island' (Numazaki 1997). Long-term commitments tended to be restricted to family members, or employees who had established family-like ties to the owning family (Hamilton and Kao 1990; Lee and Hsiao 2013).

Allied to these differences was considerable variation in the degree of delegation of control over task performance and organization, and the extent to which staff were expected to contribute to problem-solving and organizational improvements. As numerous scholars have suggested, such involvement was considerable in many Japanese companies, and in particular the role of middle-management in developing initiatives was an important feature of decision-making (Fruin 1992; Fujimoto 1999; Rohlen 1974).

Such delegation and openness to suggestions from subordinates seem to have been much lower in Korea and Taiwan, where staff were expected to follow orders and anticipate supervisors' wishes (Janelli 1993; Kim 1992; Silin 1976). Management styles tended to be more authoritarian than participative, and rarely invited independent contributions. Strategic decision-making in particular was reserved to the owning family, and often to the individual patriarch, with little initiative expected of senior and middle management.

These considerable differences between the key characteristics of the dominant post-war business systems of Japan, Korea, and Taiwan highlight the diversity of ways in which market economies can be organized while experiencing high economic growth. This diversity resulted from significant differences in the nature of the societal institutions governing economic activities in the product, capital, and labour markets, as well as in the actions of the dominant domestic political-economic coalitions and major 
surrounding powers during the early post-war period. These institutions and coalitions were nationally distinct and relatively homogenous across sectors and regions within each society, thus encouraging the establishment of nationally distinctive business systems for several decades after the war.

I now turn to a summary of their key features that help to explain the diversity of dominant post-war business systems in East Asia, before considering changes in some that may have affected the national dominance of these systems and their major characteristics in recent years.

\section{Institutional Differences in Post-War JAPAN, KOREA, AND TAIWAN}

The key institutions affecting business-system characteristics can be summarized under four main headings: the state, the financial system, the labour system, and those institutions governing trust and authority relationships (Whitley 1999, 2007). Their major features in these three societies before and during their high-growth period are listed in Table 28.2.

For much of the post-war period, the role of the state can be characterized as developmentalist in all three countries, with respect to: a) its relative autonomy from socio-economic interest groups, b) the cohesion and integration of political and bureaucratic elites, and c) their overwhelming commitment to achieving rapid economic growth (Evans 1995; Johnson 1982; Wu 2007). However, the extent of state dominance of the economic system, risk-sharing with private companies, and active promotion of particular sectors and firms differed considerably. In very broad terms, Japan's post-war democratic developmental state was less dominant and less directly involved in the direction of enterprises than its Korean counterpart after the 1961 military coup, as well as being more influenced by business associations in determining and implementing socio-economic policies. In general, the state here promoted its developmental policies more through reciprocal consent with major companies than through direct instruction (Calder 1993; Samuels 1987; Whitley 1992).

As elsewhere, a key instrument of the Japanese development state was its control of the financial system, especially during the high-growth period. The main bank system dominated corporate finance and governance until the 1980 os and was managed by the Ministry of Finance and other parts of the bureaucracy to provide ample investment funding for growing companies and to support new developments (Aoki and Patrick 1994). Strong segmentation of financial markets, restriction of the corporate-bond market, and control over branch banking enabled the state to exercise considerable power over the major banks and the flow of credit to companies.

The critical role of major banks in financing expansion during the high-growth period and institutionalization of the main bank system as the central component of 
Table 28.2 Dominant institutions affecting post-war business systems in East Asia

\begin{tabular}{|c|c|c|c|}
\hline & Japan & Korea & Taiwan \\
\hline \multicolumn{4}{|l|}{ The State } \\
\hline $\begin{array}{l}\text { State cohesion and } \\
\text { autonomy }\end{array}$ & Considerable & High & High \\
\hline $\begin{array}{l}\text { Dominant state-private } \\
\text { coalitions }\end{array}$ & $\begin{array}{l}\text { 'Iron triangle' of LDP } \\
\text { leaders, bureaucratic } \\
\text { elite, big business elite }\end{array}$ & $\begin{array}{l}\text { Military-backed } \\
\text { political elite, } \\
\text { bureaucratic elite } \\
\text { (especially EPB) and } \\
\text { chaebol }\end{array}$ & $\begin{array}{l}\text { KMT dominated political } \\
\text { and bureaucratic } \\
\text { elites, SOEs and a few } \\
\text { Taiwanese businesses }\end{array}$ \\
\hline $\begin{array}{l}\text { State commitment to } \\
\text { economic growth }\end{array}$ & High & High & High \\
\hline $\begin{array}{l}\text { State promotion of } \\
\text { particular industries }\end{array}$ & Considerable & $\begin{array}{l}\text { High, including } \\
\text { favoured firms }\end{array}$ & $\begin{array}{l}\text { Medium, but limited } \\
\text { for most Taiwanese } \\
\text { companies }\end{array}$ \\
\hline $\begin{array}{l}\text { Strength of } \\
\text { intermediary } \\
\text { organizations }\end{array}$ & Considerable & Low & Low \\
\hline \multicolumn{4}{|l|}{ Financial System } \\
\hline $\begin{array}{l}\text { State ownership } \\
\text { of banks }\end{array}$ & Low & High & High \\
\hline $\begin{array}{l}\text { State regulation and } \\
\text { segmentation of } \\
\text { financial markets }\end{array}$ & High & High & High \\
\hline $\begin{array}{l}\text { Firm dependence on } \\
\text { bank finance }\end{array}$ & High & High & $\begin{array}{l}\text { Low for most Taiwanese } \\
\text { firms }\end{array}$ \\
\hline \multicolumn{4}{|l|}{ Labour system } \\
\hline $\begin{array}{l}\text { State regulation of } \\
\text { employment } \\
\text { conditions }\end{array}$ & Considerable & High for larger firms & $\begin{array}{l}\text { High, but not strongly } \\
\text { enforced in SME sector }\end{array}$ \\
\hline $\begin{array}{l}\text { Strength of labour } \\
\text { unions }\end{array}$ & $\begin{array}{l}\text { Considerable in } \\
\text { late } 1940 \text { s, reduced } \\
\text { thereafter }\end{array}$ & Low & Low \\
\hline \multicolumn{4}{|l|}{$\begin{array}{l}\text { Authority and trust } \\
\text { relations }\end{array}$} \\
\hline $\begin{array}{l}\text { Prevalent authority } \\
\text { patterns }\end{array}$ & Paternalist & Patriarchal & Patriarchal \\
\hline $\begin{array}{l}\text { Level of trust between } \\
\text { strangers and in formal } \\
\text { institutions }\end{array}$ & Considerable & Low & Low \\
\hline
\end{tabular}


post-war corporate governance meant they became locked into the fate of their large customers and committed to their success (Aoki and Patrick 1994). These close bankfirm connections inhibited radical diversification into unrelated industries, as the main banks benefited from companies expanding existing competences and skills into related technologies and markets, rather than investing in unconnected and remote ones. Collaboration within sectors was additionally encouraged in the post-war period by state support for cooperation between firms, recession cartels, and relatively weak enforcement of anti-trust legislation (Matsuura et al. 2004).

In contrast, for most of the time before the mid-198os, both the Korean and Taiwanese states, backed by military power, pursued top-down development policies as well as owning much of the banking system. However, they differed in the extent of their active steering of firms' strategies and direct involvement in industrial development, as well as in the level of state ownership of enterprises. The post-1961 Korean state systematically used its control of banks to allocate credit at subsidized rates to favoured firms and industries, and to withdraw such financing when companies failed to meet expectations and/or engaged in antagonistic political activities (Kim 1997; Woo 1991). Business dependence on the state, especially on personal relationships with political leaders, was considerable in post-war Korea, such that large firms were unable to develop the sort of autonomy and strategic independence enjoyed by Japanese counterparts (Witt 2013b). The combination of this dependence on the military-backed regime and ample supply of cheap debt to fund expansion into state-favoured industries encouraged firms to grow so fast that they became too big to fail, and to maintain high levels of personal and family control of the chaebol. As Woo (1991:149) suggests: 'To join the hallowed chosen few, enterprises had to be big; but to remain chosen, they had to be gigantic. Size was an effective deterrent against default... big state and big business would have to sink or swim together.'

The post-1961 state's commitment to export-oriented industrialization and development of heavy industries encouraged chaebol to move rapidly into new sectors when supported by cheap credit and other incentives. Diversification into non-banking financial services was also a means of reducing dependence on state elites, as it increased financial flexibility and could facilitate access to loans. As a result, ownership-based coordination within and across industrial and service sectors has been high in Korea (Kim 1997:68-70).

Competition for state favours, both before and after industrialization, inhibited horizontal collaboration between companies and other socio-economic actors in Korea. The dominant role of the central state and its reluctance to permit independent private accumulations of wealth and control over economic activities has meant that private firms often competed through the state as well as through the market, and establishing links with industry partners was subsidiary to seeking political allies and influence. Widespread state suspicion of private alliances that could threaten its dominant role inhibited the establishment of long-term inter-firm commitments, powerful trade associations, and private cartels. 
Taiwan's post-war state was dominated by the nationalist Kuomintang (KMT) government from the mainland, which operated by martial law from 1947 to 1987 . As an external occupying force, the KMT had few, if any, ties to existing Taiwanese elites, many of whom it had destroyed after the February 1947 uprising (Gold 1986), and was long able to monopolize the political executive, bureaucracy, and legislature (Fields 1995). This control extended to the commanding heights of the economy, especially the upstream capital-intensive sectors that became mostly state owned, and the KMT itself owned extensive economic assets (Matsumoto 2002). As Wade (1990:176) puts it: 'From the early 1950 s onward Taiwan has had one of the biggest public-enterprise sectors outside the communist bloc and sub-Saharan Africa.

Similarly to Korea, a key instrument of state direction of economic development was its ownership of the major banks, which were not encouraged to lend large amounts to most Taiwanese firms (Fields 1995:66-92; Gold 1986). Despite, then, the move to a more export-oriented economy in the 1960s, under considerable US pressure, and reliance on economic growth to legitimize its rule, the KMT remained largely aloof from the Taiwanese-dominated export sector and did not attempt to coordinate or steer the development of the SMEs that constituted the bulk of these firms (Gold 1986; Wade 1990). Thus, although overall private-business dependence on the state has been quite high, the willingness and ability of state agencies to steer private firms' strategic decisions have been much less than in Korea.

This dominant yet largely remote role of the state in most Taiwanese firms' development, especially with regard to bank finance, foreign technologies, and access to markets, reinforced traditional Chinese merchants' fear of the predatory state and preference for strong owner control and secrecy. Taiwanese entrepreneurs relied heavily on informal sources of finance in which personal networks of obligation and commitment were key, and on forming collaborative partnerships for undertaking new ventures based largely on personal ties between owning families (Numazaki 1997). New networks were usually based on cliques of family members to ensure trust, but later grew around other ascriptive attributes, such as shared native place, surnames, and even birth year (Fields 1995:73; Numazaki 2000).

Turning to the institutions governing labour markets and their influence on employment policies, the radical reforms of land ownership and encouragement of labour unions by the US occupation forces in Japan between 1945 and 1952 achieved substantial changes by destroying much of the economic and political power of the landlord class and greatly increasing union membership from 381000 in 1945 to 6600000 in 1949 (Fujimura 1997; Mosk 1995:95-96). Even if membership declined in the 1950 after the 'red purge' and industry/craft based unions were increasingly replaced by enterprise unions (Garon 1997), the unions played an important role in institutionalizing seniority-based promotion, limiting flexible hire-and-fire employment policies, and encouraging long-term employer-employee commitments, especially in larger firms. In this they were supported from the late 1940s onwards by laws regulating employment conditions, dispute-resolution processes, and the supply and use of temporary workers (Inagami and Whittaker 2005; Sugeno and Suwa 1997). The combination of 
relatively long-term employment commitments, shortage of skilled workers during the high-growth period, and enterprise unions encouraged substantial delegation of control over task performance (though not necessarily work organization) to work-groups and a more facilitative style of management (Clark 1979; Dore 1973:231-242; Nakamura 1997).

In contrast, Korea's authoritarian developmental state directly controlled and manipulated labour organizations in support of export-oriented industries and ensured that wages remained relatively low (Deyo 1989; Kim 1997:120-123). Employers did not have to gain union cooperation or invest resources in gaining workers' commitment. Rapid urbanization and population growth maintained a labour surplus for many jobs and enabled the chaebol to rely on the external labour market to deal with changes in demand, especially for manual workers. Traditional patterns of authority, coupled with the dominant role of the military after 1961 and difficulty of establishing trust relations beyond kinship and other particularistic connections, limited delegation of authority and discretion in most chaebol (Bae 1987; Janelli 1993; Kim 1992). Additionally, traditional disdain for manual workers and less-educated employees tended to restrict longer-term employment commitments to college-educated white-collar staff, though this appeared less firm in Korea than in large Japanese firms (Bae 1987; Janelli 1993).

In Taiwan, the KMT-dominated state also exercised strong control over the labour movement, encouraging enterprise-based unions that could not bargain over wages and making the appointment of officials subject to the approval of local KMT committees (Deyo 1989:117-118). These unions were more concerned with providing member services than representing workers' interests, and reinforced traditional employer paternalism. Additionally, many factory workers viewed employment as a temporary status before starting their own business and strongly preferred self-employment, not least because of the reluctance of most owner-managers to delegate decision-making (Fields 1995:73-74; Numazaki 1997; Shieh 1992).

The combination of an authoritarian, ethnically distinct state apparatus, limited regulation of employment relations in the SME-dominated private sector, traditional reliance on family-like particularistic ties in trust relationships, and patrimonial patterns of authority has limited the development of credible commitments between employers and most employees in post-war Taiwan, as well as restricting the substantive decentralization of authority and task performance. Such restriction was reinforced by the traditional Confucian legitimation of power, which stressed the moral superiority of leaders, that continued to be important in Taiwan as the Nationalists relied extensively on the doctrines of Sun Yat-sen in their legitimating ideology, justifying the tutelary role of the state and the wide discretion allowed to senior officials in managing the economy (King 1996). As Wade (1990:286) puts it: 'Those near the top of bureaucratic hierarchies are assumed to have reached their position by their superior knowledge and strength of moral character, which frees them from the constraints of formal law...the imperial scholar-official tradition taught officials to feel superior to their business clients and to exercise leverage with them. Today's officials are descendants of that tradition. 


\section{Changes in Dominant Institutions in EAST ASIA, 1980-2010}

Some of these institutional features have altered considerably in the last thirty or so years, along with major shifts in the wider political and economic environment, and there has been much discussion about whether these developmental states are being reformed in a 'liberal' market economy direction (Beeson 2009; Fields 2012; Weiss 2004). Equally, the growth of transnational investment and trade flows, coupled with attempts to increase the amount and effectiveness of transnational economic governance (Braithwaite and Drahos 2000; Djelic and Quack 2003; Djelic and Sahlin-Andersson 2006), can be seen as weakening national institutions' influence on leading firms' structures and behaviour in East Asia, such that nationally specific business systems are becoming less homogenous and distinctive (Lechevalier 2007; Sako 2006). In this section, I compare major changes in dominant institutions in each of these societies (Table 28.3), as a prelude to considering how these have led to shifts in the dominant characteristics of the post-war business systems discussed above.

Perhaps the most significant shifts have taken place in the structure and policies of the developmental state, as the cohesion of political and bureaucratic alliances with big business, especially in Japan and Korea, weakened and economic growth became less overwhelming as the focus of public policy-making (Fields 2012; Wu 2007). The recent relative decline in the autonomy of the state and its pursuit of export-oriented industrialization in all three societies was accompanied by a variety of measures aimed at liberalizing product, capital, and labour markets as international competition intensified and geo-political alliances were reorganized (Gray 2011; Song 2012; Thurbon and Weiss 2006). However, these broad changes in dominant coalitions, institutions governing capital and labour markets, and public policies occurred in different ways and with varied consequences for business systems (e.g. Fields 2012; Lee 2009; Zhang 2009, 2012).

The most far-reaching and radical institutional changes occurred in Korea and Taiwan, where democratization, political competition, and the establishment of independent interest groups, especially organized labour, developed in the late 1980 and 1990s. Although policies fluctuated, especially with regard to the liberalization and reregulation of financial markets before and after the Asian financial crises of 1997-98, both societies underwent political reforms that changed the make-up of dominant coalitions and of the policies pursued (Thurbon 2001; Fields 2012; Zhang 2012).

In Korea, the advent of electoral democracy after 1987 led to the formation of a conservative coalition that supported an expansion of bank-lending to farmers and SMEs at the same time as enabling the chaebol to maintain their dominant economic position and accessing the growing corporate-bond market for investment funds. Within the bureaucracy, the previously dominant Economic Planning Board was merged with the Ministry of Finance in 1995, and the new Ministry of Finance and Economy became more influenced by advocates of financial liberalization. While privatization 
Table 28.3 Major changes in dominant institutions in Japan, Korea, and Taiwan, 1980-2010

\begin{tabular}{|c|c|c|c|}
\hline & Japan & Korea & Taiwan \\
\hline \multicolumn{4}{|l|}{ The State } \\
\hline $\begin{array}{l}\text { State cohesion and } \\
\text { autonomy }\end{array}$ & Reduced & Reduced & Reduced \\
\hline $\begin{array}{l}\text { Dominant state-private } \\
\text { coalitions }\end{array}$ & $\begin{array}{l}\text { Weakening of 'iron } \\
\text { triangle', limited } \\
\text { inclusion of trade } \\
\text { union federation }\end{array}$ & $\begin{array}{l}\text { Some expansion to } \\
\text { include SMEs, farmers } \\
\text { and workers }\end{array}$ & $\begin{array}{l}\text { Expansion to include } \\
\text { Taiwanese-owned large } \\
\text { business groups }\end{array}$ \\
\hline $\begin{array}{l}\text { Dominance of economic } \\
\text { growth priorities }\end{array}$ & Reduced & $\begin{array}{l}\text { Reduced, but still } \\
\text { strong }\end{array}$ & Reduced, but still strong \\
\hline $\begin{array}{l}\text { State promotion of } \\
\text { industries }\end{array}$ & $\begin{array}{l}\text { Considerable, but more } \\
\text { indirect }\end{array}$ & $\begin{array}{l}\text { Considerable, but less } \\
\text { dirigiste }\end{array}$ & $\begin{array}{l}\text { Considerable in newer } \\
\text { sectors }\end{array}$ \\
\hline $\begin{array}{l}\text { Strength of intermediary } \\
\text { associations }\end{array}$ & Considerable & $\begin{array}{l}\text { Increased, but still } \\
\text { limited }\end{array}$ & $\begin{array}{l}\text { Increased, especially in } \\
\text { new ICT sectors }\end{array}$ \\
\hline \multicolumn{4}{|l|}{ Financial System } \\
\hline $\begin{array}{l}\text { State ownership of } \\
\text { banks }\end{array}$ & Low & $\begin{array}{l}\text { Reduced, but chaebol } \\
\text { ownership still } \\
\text { restricted }\end{array}$ & $\begin{array}{l}\text { Reduced, but still } \\
\text { significant }\end{array}$ \\
\hline $\begin{array}{l}\text { Dependence of firms on } \\
\text { bank finance }\end{array}$ & $\begin{array}{l}\text { Reduced for larger } \\
\text { successful firms, high } \\
\text { for others }\end{array}$ & $\begin{array}{l}\text { Reduced for largest } \\
\text { chaebol, increased for } \\
\text { SMEs }\end{array}$ & $\begin{array}{l}\text { Increasing use of } \\
\text { capital markets, but } \\
\text { bank finance remains } \\
\text { important }\end{array}$ \\
\hline $\begin{array}{l}\text { State regulation and } \\
\text { segmentation of } \\
\text { financial markets }\end{array}$ & Considerably reduced & Considerably reduced & $\begin{array}{l}\text { Considerably reduced, } \\
\text { but state regulation } \\
\text { remains strong }\end{array}$ \\
\hline \multicolumn{4}{|l|}{ Labour system } \\
\hline $\begin{array}{l}\text { State regulation of } \\
\text { employment conditions }\end{array}$ & $\begin{array}{l}\text { Reduced, but more } \\
\text { than USA/UK }\end{array}$ & $\begin{array}{l}\text { Reduced, but still } \\
\text { significant }\end{array}$ & $\begin{array}{l}\text { Reduced, but still } \\
\text { significant in SOE sector }\end{array}$ \\
\hline Union strength & $\begin{array}{l}\text { Reduced, enterprise } \\
\text { unions remain strong } \\
\text { in large firms }\end{array}$ & $\begin{array}{l}\text { Increased in late } 1980 \mathrm{~s}, \\
\text { reduced in } 2000 \mathrm{~s}\end{array}$ & $\begin{array}{l}\text { Considerable in SOE } \\
\text { sector, low elsewhere }\end{array}$ \\
\hline \multicolumn{4}{|l|}{ Authority and trust } \\
\hline $\begin{array}{l}\text { Prevalent authority } \\
\text { patterns }\end{array}$ & Paternalist & Less authoritarian & Less authoritarian \\
\hline $\begin{array}{l}\text { Trust of strangers and } \\
\text { in formal institutions }\end{array}$ & $\begin{array}{l}\text { Declining trust of } \\
\text { state agencies }\end{array}$ & Low & Low \\
\hline
\end{tabular}


of state-owned banks and other SOEs remained slow, non-bank financial institutions (NBFIs) expanded fast, and supplied chaebol with relatively cheap credit. According to Thurbon (2001:242), Korea's liberalization process in the 1990s was 'rapid, reckless and ill-designed ... accompanied by the build-up of massive amounts of short-term foreign debt, over-investment in critical export industries and a debt-riddled banking sector'.

After the 1997-98 financial crises, deregulation of both financial and labour markets became more wide ranging, partly at the behest of the IMF and other international agencies. However, equity markets remained relatively illiquid and unimportant in providing investment capital, compared to the expanding bond market and foreign investors (Zhang 2012). With the election of Kim Dae Jung in 1997, interest groups that had largely been excluded from policy considerations, particularly labour unions, gained in political influence as the new regime sought to restrict chaebol power more effectively, especially after some required state support. Bank lending to SMEs continued to grow substantially, while the NBFIs were reined in, and the central bank gained some independence, along with the newly established Financial Supervisory Commission. Despite the chaebols' reluctance to embrace equity financing if it meant a loss of control, the opening of capital markets to outsiders-albeit somewhat hesitant-led overseas investors to amass 40 per cent of issued shares on the Korean stock exchange in 2005, mostly in the largest listed companies and banks. The Capital Market Consolidation Act, passed in 2007 , aimed to remove barriers between financial markets, but restrictions on industrial firms owning financial companies remain and in general Korea's financial markets are still dominated by the larger banks and their supervisors (Zhang 2012).

In the aftermath of democratization and lifting of some restrictions on labour organizations, union membership grew considerably and led to the establishment of the independent Korean Confederation of Trade Unions, although this only achieved official recognition after the 1997-98 financial crises and Kim Dae Jung's election. As Lee (2009) emphasizes, while the unions were successful in gaining wage increases and reductions in the working week, at least in larger companies, after 1987 the state continued to repress independent unions and take an active role in managing labour disputes, which remained confrontational. After 1997-98, however, the state more formally institutionalized semi-corporatist consultation processes and extended unions' legal rights as part of a trade-off for enabling redundancies in large firms (Kong 2006; Song 2012; Witt 2013b). Such forced reductions in the numbers of regular workers were dependent on significant enterprise restructuring, usually by selling off more peripheral subsidiaries to pay down debt, and substantial restrictions on dismissing such employees in major companies remain, as does strong and effective union resistance to such redundancies (Song 2012).

In Taiwan, in contrast, the lifting of martial law in 1987 and Taiwanization of the ruling KMT encouraged closer links between the state and private business groups, as policy-makers sought to play a more active role in promoting high-technology industries and gain popular support (Fields 2012). This included the encouragement of stronger business associations, especially in the newer sectors (Tung 2001), although some of the largest business groups preferred to deal with the state through direct personal contacts rather than to participate in the construction of effective collective 
associations (Zhang and Whitley 2012). Both the KMT and main opposition party, the Democratic Progressive Party (DPP), supported the expansion of capital markets and liberalization of the banking sector, but more cautiously and incrementally than in Korea (Thurbon 2001; Wu 2007). The Central Bank of China and Ministry of Finance gained influence and pushed through regulatory reforms to boost the Taipei Stock Exchange (TSE) and encourage institutional investment, leading to much larger TSE capitalization and liquidity than in its Korean counterpart (Zhang 2009, 2012), as well as allowing business groups to establish private banks and, eventually, financial holding companies.

Whereas the dominant role of the chaebol in Korea during the high-growth period and their close association with the military-backed authoritarian regime had led the opposition movement to remain antagonistic to them when it eventually succeeded in winning the presidency, the relatively low profile and detached nature of most Taiwanese business groups from the KMT party-state meant that the DPP developed quite close ties to many of them, initially at local level and then nationally. As a result, when the DPP won the presidency in 2000, government-business links did not weaken greatly, despite the opposition's previous support for labour-union interests. Indeed, if anything, the influence of some business groups on economic policies and priorities may well have increased, and some suggest that corruption intensified (Copper 2009; Wu 2007). The autonomy of the state and its capacity for pursuing developmental economic goals in opposition to the short-term interests of big business have, then, declined in Taiwan relative to its position in the 1960 s and 1970s, as the economic bureaucracy became more controlled by elected politicians competing for support from major interest groups (Lee and Hsiao 2013; Wu 2007:986).

As Lee (2009) makes clear, the political role of the independent unions was quite different in Taiwan from that in Korea. Because large enterprises were mostly state- or KMT-owned in Taiwan before democratization, and the KMT sought to incorporate the organized labour movement into the party-state regime, the bulk of the union membership worked in the state-owned and/or controlled-enterprise sector and was only weakly represented in SME-dominated industries. Despite being denied official recognition at the national level, the existence of elected administrations at local and regional levels enabled opposition groups to support independent union activities and ensured that unions could become political actors, at first locally, but eventually nationally (President Chen granted de facto recognition of the Taiwan Confederation of Trade Unions in 2000).

Since the unions were overwhelmingly represented in the state-dominated sector, they were able to use their political influence after electoral competition was established to obtain wage increases in ways that their Korean counterparts could not. However, their weakness in the private sector-and relatively low membership, at under 10 per cent once the craft unions of largely self-employed workers are excluded (Kong 2006:370) has limited wage increases since 1987. Similar political manoeuvrings in the late 1990s and 2000 s enabled the unions to slow down, and sometimes prevent, the pace of privatizations of SOEs and to protect workers against sudden and large-scale redundancies. By 2002, Taiwan still had ninety-seven SOEs contributing 10.2 per cent of GDP, while Korea 
only had thirty-five, contributing 5.3 per cent of GDP (Lee 2009), although more have been privatized since then, albeit with quite strong union involvement.

While political democratization in both societies seems to have encouraged a more responsive pattern of leadership, at least for the major interest groups, it remains unclear whether prevalent authority patterns will become much more reciprocal for others and justified in more communitarian terms. As Lee and Hsiao (2013) and Witt (2013b) point out, trust in strangers and formal institutions remains limited in both Korea and Taiwan, despite political changes, and family-like patterns of commitment and trust continue to form the basis of major economic transactions.

Institutional change in Japan has been rather less dramatic, and may be more formal than realized in practice. While the 'iron triangle' of political, bureaucratic, and big-business élites has weakened, it would be misleading to claim that the developmental state has withered away, or that shifting dominant coalitions of politicians, bureaucrats, and business leaders no longer see the state playing a major-if not the central—role in coordinating and promoting economic growth (Witt 2013a). Few senior managers actively seek the abolition of state regulation of market behaviour and, as Fields (2012:3) suggests, 'even as bureaucrats and capitalists have "remodelled" industrial policies and refashioned corporate strategies...the state's developmental orientation and substantive intervention and private capital's continued reliance on its corporate and bureaucratic networks have persisted'.

What does seem to have changed is the level of direct intervention and guidance of business strategies as product, capital, and labour markets have become more liberalized since the 1970 and the state has pursued more indirect ways of upgrading technologies and supporting new industries. The 1999 Industry Revitalization Law and its 2003 revisions, for example, provided state support for declining industries while encouraging private investment in growth sectors and joint ventures for innovative technologies (Fields 2012). While the reconstituted Ministry of Economy, Trade and Industry supported some neo-liberal reforms, it also played a significant role in boosting bottom-up strategic alliances and promoting collaboration between state agencies, firms, and universities to advance new technologies.

Substantial reforms to the financial system, culminating in the 'big bang' changes of 1996-2001, liberalized capital markets, gave the Bank of Japan formal independence, and removed barriers between financial markets, as well as permitting the formation of holding companies (Laurence 2001). Over time, they led to foreigners owning 26 per cent of issued shares on the Tokyo Stock Exchange in 2009, substantial mergers of banks, insurance companies, and other financial institutions, as well as some reduction in the level of cross-shareholdings between firms. Additionally, there has been a limited expansion of private equity and similar means of funding new companies, albeit from a very low baseline (Sako and Kotosaka 2012).

However, many bank and securities firms' mergers were more defensive than a radical break from the past, and bank-led finance continues to be significant for many Japanese firms, especially those unable to obtain funding from corporate bond markets. As Fields (2012) suggests, there remain substantial coalitions of interests willing and able to resist radical changes in a number of markets, including financial services, and these appear 
to have restricted the shift towards a more capital market-based system, despite the establishment of new stock exchanges, such as JASDAQ and MOTHERS, for start-ups, and some changes in prevalent forms of venture capital.

Changes in labour-market institutions in Japan have also supported some liberalization of regulations governing employment conditions and use of non-regular workers. In particular, the employment of agency workers and other temporary staff has become more widely permitted and such workers can be used across a wider range of tasks than was common before the 1990s. Non-regular workers increased from 20.2 per cent of the labour force in 1990 to 32.3 per cent in 2008 , and 12.6 million people worked part-time in 2002 (Sako 2006:210). However, much of the growth in non-regular employment seems to have occurred amongst the 25-34 age-group and women in part-time roles in the health and welfare service sectors, and so reflects an increased variability of employment conditions between different parts of the economy, rather than a qualitative shift in established patterns in longer-established industries (Witt 2013a).

Although the strength of labour unions overall may have declined, with union membership falling to 23.8 per cent of the workforce in 1995 and 18.7 per cent in 2005, and the Shunto spring offensive losing much of its coordinating role in national wage-bargaining (Sako 2006), enterprise unions retain significant influence over corporate decisions in most large companies, and the labour movement as a whole has become more unified and involved in policy discussions (Shinoda 1997; Walter and Zhang 2012). Furthermore, core workers in large firms seem to continue to benefit from regulatory restrictions on dismissal and relatively long-term employment commitments remain common, for this group at least (Jackson 2007; Song 2012). Equally, while performance-based pay has become more important at an earlier age in many companies, it remains limited to more senior staff, and seniority in general is still a significant component of wage increases (Keizer 2009, 2011).

Although recent scandals amongst politicians and bureaucrats may well have reduced the level of trust in state agencies, as witnessed perhaps by recent sizeable demonstrations against nuclear power stations, and possibly encouraged the rise of NGOs in Japan, overall willingness to trust strangers and formal institutions seems to remain quite high, especially compared with elsewhere in Asia (Witt 2013a). Japan continues to be a highly networked society in which both formal and informal reputations play a considerable role in policing behaviour, and communitarian justifications of authority seem to remain significant components of organizational cultures (Inagami and Whittaker 2005).

\section{East Asian Business Systems in THE 21ST CENTURY}

Given these changes in many of the dominant institutions and interest groups governing economic activities in these societies, it would be surprising if at least some of the post-war characteristics discussed above have not also altered. However, not all recent 
changes have been so mutually reinforcing that they can be expected to generate significant shifts in a particular direction, and in some countries they have stimulated substantial and effective resistance from key interest groups. Consistent and systemic changes in dominant business-system characteristics towards, for example, those seen as emblematic of Anglo-American capitalism, are less evident than some have expected.

The gradual loosening of many restrictions on firm behaviour in capital and labour markets in some states can, though, be expected to have encouraged greater strategic heterogeneity amongst leading companies, especially those encountering diverse technological and market conditions in different parts of the world, and to have weakened the complementarity of major institutions in encouraging homogenous patterns of economic coordination and control across sectors and regions within national boundaries. Given that the post-war dominance of state agencies and particular political-bureaucratic elites in steering economic development has declined in the societies considered here (Weiss 2010; Wu 2007), an obvious question arises about the continued national specificity and distinctiveness of their post-war business systems and the extent to which these continue to reflect the dominant ways of organizing economic activities across the larger and more complex economies.

Has the standardizing role of the developmentalist state become so reduced in East Asia as to permit the variety of firm-governance practices and strategic priorities found in some liberal market economies, or would it be more accurate to discern, in the mixture of homogeneity and heterogeneity in economic coordination and control, patterns seen across different industries and regions in some European societies (Boyer 2004; Schmidt 2002)? Relatedly, to what extent has the growing internationalization of investment and operations of many Japanese, Korean, and Taiwanese firms, and somewhat less widespread opening of these domestic economies to foreign portfolio and strategic investments, so altered these patterns within national boundaries as to render the idea of nationally distinct and dominant business systems in East Asia less convincing than in the heyday of the developmental state?

While definitive answers to these sorts of questions require more sustained discussion than feasible here, recent collections (e.g. Aoki, Jackson, and Miyajima 2007; Walter and Zhang 2012; Colpan, Hikino, and Lincoln 2010), together with other analyses, permit some tentative conclusions. In Table 28.4 I have suggested how the major post-war characteristics outlined above seem to have altered over the past three decades as a result of institutional changes and more general shifts in the global business environment.

\section{Japan}

In Japan, the considerable restructuring of post-war inter-market groups and banking system that has taken place since 1991 has, together with the fluctuating growth of foreign shareholdings in some of the largest companies, further hastened the decline of the main bank system for many of the more successful firms, especially regarding the effectiveness of the bank and keiretsu monitoring of corporate performance (Lincoln and 


\section{Table 28.4 Changing East Asian business system characteristics, 1980-2010}

\begin{tabular}{|c|c|c|c|}
\hline $\begin{array}{l}\text { Dominant Business } \\
\text { System Characteristics }\end{array}$ & Japan & Korea & Taiwan \\
\hline \multicolumn{4}{|c|}{ Ownership-based integration } \\
\hline $\begin{array}{l}\text { Owner-manager } \\
\text { relationships }\end{array}$ & $\begin{array}{l}\text { Committed except for } \\
\text { firms with large } \\
\text { numbers of foreign } \\
\text { shareholders }\end{array}$ & Direct & Direct \\
\hline Vertical integration & Medium & High & $\begin{array}{l}\text { Increased in some } \\
\text { business groups, but still } \\
\text { mostly limited }\end{array}$ \\
\hline Horizontal integration & Medium & $\begin{array}{l}\text { High for most chaebol, } \\
\text { but less than in 1980s }\end{array}$ & $\begin{array}{l}\text { High for most business } \\
\text { groups }\end{array}$ \\
\hline \multicolumn{4}{|c|}{ Alliance-based Integration } \\
\hline Vertical integration & $\begin{array}{l}\text { Reduced in large firms } \\
\text { that have invested } \\
\text { abroad and in some } \\
\text { new industries }\end{array}$ & Low & $\begin{array}{l}\text { Expansion of } \\
\text { centre-satellite } \\
\text { hierarchical alliances with } \\
\text { state support }\end{array}$ \\
\hline Horizontal integration & $\begin{array}{l}\text { Weakened in } \\
\text { restructured } \\
\text { inter-market groups }\end{array}$ & Low & $\begin{array}{l}\text { Limited, except for } \\
\text { kinship-based alliances }\end{array}$ \\
\hline \multicolumn{2}{|c|}{ Competitor collaborationConsiderable } & Low & $\begin{array}{l}\text { Increased, but mostly } \\
\text { short-term except for } \\
\text { kinship-based alliances }\end{array}$ \\
\hline \multicolumn{4}{|c|}{ Organizational integration and commitment } \\
\hline $\begin{array}{l}\text { Employer-employee } \\
\text { commitment }\end{array}$ & $\begin{array}{l}\text { Reduced in some new } \\
\text { sectors and MNCs, } \\
\text { considerable in most } \\
\text { large firms }\end{array}$ & Low & Limited \\
\hline $\begin{array}{l}\text { Delegation to, and } \\
\text { involvement in } \\
\text { problem solving of, } \\
\text { the bulk of the regular } \\
\text { workforce }\end{array}$ & $\begin{array}{l}\text { Considerable in many } \\
\text { large firms }\end{array}$ & Low & Low \\
\hline $\begin{array}{l}\text { Overall Homogeneity } \\
\text { of Business-System } \\
\text { Characteristics }\end{array}$ & $\begin{array}{l}\text { Reduced, especially } \\
\text { for newer firms } \\
\text { and MNCs, but still } \\
\text { considerable }\end{array}$ & $\begin{array}{l}\text { Despite some } \\
\text { restructuring of } \\
\text { chaebol, still } \\
\text { considerable }\end{array}$ & $\begin{array}{l}\text { Increasing dominance } \\
\text { of family-controlled } \\
\text { business groups, with } \\
\text { some differences between } \\
\text { sectors }\end{array}$ \\
\hline
\end{tabular}


Shimotani 2010). However, the decline in bank control and share ownership that accelerated in the late 1990s (Miyajima and Kuroki 2007) has not radically reshaped ownermanager relationships, as predicted by some. As Nakamura (2011) indicates, financial institutions as a whole, including trust funds run by many banks, still owned 32.4 per cent of shares listed on the Tokyo Stock Exchange in 2008, with a further 22.4 per cent owned by non-financial companies, and the latter figure represented an increase from earlier in the 2000s, as many companies sought to protect themselves against hostile takeovers. While, then, some of the largest Japanese firms that have been successful in export markets have attracted substantial foreign investment and secured much of their externally provided funding from the corporate-bond market over the past three decades, committed ownership still seems to constitute the dominant form of ownermanager relationships in the Japanese economy, with market-based forms remaining a limited phenomenon with little impact on firm behaviour (Jackson 2007).

Considering changes in ownership- and alliance-based coordination and integration of economic activities, the 'withering away' of some keiretsu discerned by Lincoln and Shimotani (2010) suggests an overall reduction in the degree of both vertical and horizontal coordination through alliance networks, as well as some-but not massive-increase in large-firm incorporation of supply-chain alliance partners into fully owned subsidiaries. However, as Kikutani, Itoh, and Hayashida's (2007) analysis of business-portfolio restructuring in the 1990s suggests, the degree of vertical specialization of large Japanese firms in general seems likely to remain considerable, and much greater than in Korean chaebol or their American counterparts.

In some industries, such as parts of the consumer-electronics sector, where technological modularization has increased, alliance-based vertical integration within Japan may have declined as the largest firms relocated some operations abroad and began to cultivate foreign suppliers. However, the continuing limited extent of backward integration through full ownership in many sectors and extensive commitment to supplier learning and capability improvement observed in vehicle production and other sectors (MacDuffie and Helper 2006; Sako 2006) suggest that relational contracting and vertical alliances remain significant characteristics of Japan's contemporary business system. Even in the modularized electronics industry, the outsourcing of some standardized, high-volume component production to Taiwanese and other suppliers on a more arm's-length basis has been accompanied by the formation of numerous alliances within Japan to develop new products and technologies and a number of joint factory investments from which it will be difficult to withdraw (Sturgeon 2006).

Equally, while Kikutani et al. (2007) describe considerable levels of industry exit and entry by large companies in the 1990s, this activity does not seem to have resulted in significant changes to the overall level of ownership-based horizontal integration, especially to the extent of market and technologically unrelated diversification, which remains relatively limited in an Asian context. There is also little evidence that the weakening and restructuring of post-war keiretsu relationships have significantly reduced the level of collaboration and cooperation between competing firms in most product markets, not least because the state has continued to promote such cooperation in declining 
industries, and for the development and diffusion of new technologies. As Nakamura (2011:195) suggests, product-market competition remains relatively weak in Japan, and Amable (2003:123) claims that 'Japan is also characterized by opacity and emphasis on outward-oriented policies, meaning that protection against competition is stronger than in other members of the cluster (Germany, France, Belgium)'.

In the light of changes in employment regulations intended to enhance flexibility and external mobility (Inagami and Whittaker 2005:31-32), and the internationalization of some operations by Japanese firms, it might be expected that the three pillars of the post-war employment system-long-term employment, seniority-linked pay, and enterprise unions-would have undergone substantial changes after the collapse of the bubble economy. However, the evidence for widespread and significant restructuring of these pillars remains limited, and employer-employee commitments continue to be considerable, particularly for male workers over 30 in the larger firms (Keizer 2009, 2011; Inagami and Whittaker 2005). While this is partly because the regulatory environment remains quite restrictive despite the recent changes (Jackson 2007), it also reflects a widespread belief amongst Japanese employers, including many smaller ones, that long-term commitment to company success on the part of the core workforce represents a crucial component of a firm's competitiveness.

This is not to deny the considerable growth of 'non-regular' and part-time employment and performance-based pay, especially in some sectors and for some staff (Song 2012). However, the significance of these can be overstated and-like many of the heralded changes to corporate governance practices (Dore 2007)-may represent more an accretion of innovations to established practices than their overthrow (Witt 2013a). Performance-based pay, for instance, seems to be limited to senior staff and affects bonus payments rather than influencing promotion, which largely remain seniority-based for many grades (Keizer 2011).

There is, though, some evidence of increasing variability of employment practices, as indicated by a number of surveys in the early 200os. While over 80 per cent of companies responding to a METI survey claimed to be committed to long-term employment for core workers, another survey, conducted by the Policy Research Institute of the Ministry of Finance, indicated that a number of firms are combining corporate governance characteristics with employment policies in novel ways, to constitute different kinds of hybrid companies (Jackson 2007; Jackson and Miyajima 2007).

The same Ministry of Finance survey suggested that employee involvement in strategic decision-making remained quite significant in many Japanese companies, particularly for issues concerning employment policies and practices (Miyajima and Kuroki 2007). About half the firms claimed that decisions about production and sales planning and profit indicators involved discussions with unions, while over half considered that employee stock-ownership proposals and corporate restructuring also required some explanation or agreement. In 63 per cent of cases, employment adjustment was thought to require union agreement. Such continued delegation to, and involvement of, core workers in problem-solving, task performance, and some corporate decisions remain a distinctive feature of many Japanese companies (Witt 2013a). 
Overall, then, there is some evidence of a decline in the homogeneity of firm governance and behaviour and in the extent to which the national economy is highly coordinated, following a reduction of state cohesion and autonomy and the weakening of keiretsu and the coordinating role of the shunto wage-bargaining system (Lechevalier 2007; Sako 2006). However, if some reduction in the high level of institutional complementarities has enabled firms to develop somewhat more diverse coordination and control patterns, it is remarkable how much of the post-war business system seems to remain widespread. Zero-sum arm's-length competition between isolated hierarchies is still unusual in many industries and there are few signs of an active market for corporate control developing. Firms remain dominated by insider interests and average employment tenure-periods remain considerable. Given the contradictory nature of many institutional reforms, and the continued strength of interest groups opposing extensive liberalization of many markets, this is perhaps not too surprising.

\section{Korea}

Considering the changes in dominant business-system characteristics in Korea, it is clear from recent analyses that family control remains considerable, if not indeed dominant, despite reductions in the direct shareholdings of top managers. This is typically achieved through pyramidal structures and complex inter-firm share ownership. According to a recent Korean Free Trade Commission report, internal ownership (i.e. the combination of direct family with inter-corporate shareholdings) of the largest ten chaebol was over 50 per cent (Aguilera et al. 2012), and Almeida et al. (2009) have shown that the average level of family and associated firms' consistent voting rights in 1085 member companies of the top 47 chaebol between 1998 and 2004 was 68 per cent.

Furthermore, despite considerable reforms of the formal corporate governance system designed to encourage outside investors by increasing transparency and reducing the manipulation of subsidiary accounts following the 1997-98 financial crisis and the election of Kim Dae Jung, widespread scepticism remains about their implementation and enforcement (Walter and Zhang 2012; Witt 2013b). The increase in foreign share ownership to 16.3 per cent in 2009 and in direct financing of the chaebol from the corporate-bond market has not resulted in a general move to market-dominated investor-manager relationships.

Similarly, while post-crisis political pressures to reduce the degree of unrelated diversification pursued by many chaebol may have resulted in some reduction in the extent of horizontal ownership-based integration, it remains considerable, particularly as they expanded into non-bank financial services in the 1980s and 1990s (Choe and Roehl 2007; Kim et al. 2004; Zhang 2012). The average number of two-digit industries in the Korean SIC code in which member firms of the top thirty chaebol were active-excluding the financial sector-rose from 9.9 in 1987 to 14.5 in 1997 and then declined to 10.0 in 2006 (Kim 2010). Vertical integration also remains high, even in modularized industries such as consumer electronics, as exemplified by Samsung Electronics. It should be 
noted, though, that not all chaebol are equally diversified, as the comparison of how the Hyundai and LG chaebol responded to the 1997-98 crisis revealed (Kim et al. 2004). After a long and bitter dispute between members of the family controlling the Hyundai chaebol, the Hyundai Motor group that emerged as a separate entity has followed a much more focused strategy than the LG group.

Attempts to boost the size and economic significance of SMEs as independent actors and counterweights to the chaebol seem to have had little effect on subcontractors' autonomy from their largest customers, and inter-firm networks in Korea tend to be chaebol-centred, vertical and exclusive (Witt 2013b). Overall, the level of alliance-based coordination between large and small firms remains relatively low, as does inter-firm collaboration and cooperation (Hsieh 2011; Walter and Zhang 2012).

Considering the next changes in employment relations and managerial authority, the liberalization of some restrictions on external labour mobility for regular workers after the financial crisis enabled chaebol to make large-scale redundancies in the late 1990 os in conjunction with significant restructuring of their sprawling empires, as well as introducing more individualized merit-based reward systems (Kim et al. 2004). According to Park and Kim (2008), over 70 per cent of listed manufacturing firms significantly reduced employee numbers in 1998 and average job tenure in Korean firms as a whole remains low, though increasing for workers in large companies (Song 2012; Witt 2013b).

Equally, many firms used the opportunities created by labour-market reforms to increase the use of non-regular and employment-agency workers considerably, thus reducing their core workforce, for whom organizational careers remained a realistic expectation. Particularly in more technologically advanced industries, many large firms combined increasing numerical flexibility with reinforced internal career hierarchies, to develop greater organizational commitment amongst skilled technical staff (Deyo 2012). In general, the two-tier labour market characteristic of the high-growth period has continued, and indeed become more intensified (Song 2012), but employment contingency is being extended to the growing ranks of skilled and technical labour in larger companies.

While there is still little evidence of democratization stimulating widespread change in the prevalent authoritarian management style, with most chaebol decision-making being highly centralized (Kim et al. 2004; Witt 2013b), a few case studies in the electronics and ICT industries suggest that some Korean companies are both capable and willing to involve employees in problem-solving and, in an Internet start-up, developing new products and services (Kim and Bae 2005; Lee, Rho, and Kim 2007). However, even when so-called high-performance work organization, involving considerable task-performance delegation to workers, has been adopted by large companies, it tends to be imposed top down, following the lean-production model, rather than developed collaboratively with employee representatives, especially where a firm, like Samsung, follows a doctrinaire non-union policy (Kim and Bae 2005).

Overall, then, it seems that the significant changes in the Korean business environment following democratization in 1987, violent labour disputes in the late 1980s, and the 1997-98 financial crisis, as well as the weakening of the strong developmentalist state 
in the 1990s (Weiss 2004), and numerous political attempts to reorganize the chaebol, have failed to alter the dominant characteristics of the post-war business system to any great extent. In particular, the domestic economy remains dominated by very large, very diversified family-controlled conglomerates engaging in adversarial, zero-sum competition with other firms, and continuing to exploit their market power over SMEs. Extra-firm coordination of economic policies and development of collective competition goods continues to be limited, although employers' federations seem to have gained some autonomy, and employer-employee commitments are mostly short term. While this situation might be thought surprising given the extent of institutional change since 1980, it becomes more explicable by considering the following points.

First, the weakening of the developmental state and its move towards a more regulatory approach to economic coordination and steering were not accompanied by the mobilization of strong interest groups that could form a dominant coalition in opposition to the chaebol. The labour-union movement remains divided between two major federations and was neither strong enough to prevent the easing of restrictions on enforced redundancies in larger firms, nor to provide major support for government attempts to restructure the chaebol. It did, however, succeed in expanding the social safety-net for the unemployed and, more widely, the welfare state (Peng and Wong 2008).

Second, although the chaebol as a whole were weakened both economically and politically by the 1997-98 financial crisis, those that survived seem to have successfully internationalized their activities with improved and innovative products. These conglomerates became stronger and more able to resist and/or circumvent many of the corporate-governance reforms, sometimes by invoking nationalist sentiments against foreign takeovers and entry into markets such as banking.

Third, the continuing weakness of most SMEs, and the tendency of many chaebol to absorb any that promise to be successful, has meant that policy-makers have had little choice but to work with the large conglomerates when seeking to upgrade the skills and capabilities of Korean firms and help them compete effectively in international markets and new industries. With the revival of state planning and coordination of economic development in the 2000 s and chastening experiences from somewhat ill-thought out and poorly implemented neo-liberal policies in the 1990 (Thurbon 2001), the dominant developmental state of the 1960-1980s is implementing a more collaborative form of industrial policy in which some chaebol remain key actors, thus limiting its ability to enforce their radical transformation (Weiss 2004, 2010).

\section{Taiwan}

As Lee and Hsiao (2013) emphasize, ownership and control of most firms in Taiwan remains dominated by families, including the largest business groups, which have come to play the leading role in the economy since democratization (Chung 2004), with 62 of the largest 100 groups being family owned or controlled in 2006. Similarly, Chung 
and Mahmood (2010:196-197) found that 'many of the ultimate owners of group affiliates were in fact private holding companies and investment companies that were controlled by the family... The pyramid is a multiple-level ownership network constructed by chains of inter-organizational shareholding... Through this mechanism, the controlling family can control the whole group by maintaining sufficient equity only in the controlling centre' in much the same way as the Korean chaebol. Despite the liberalization of many financial markets and the formation of privately controlled financial holding-companies, institutional ownership of large firms' shares, while increasing, remains limited (Zhang 2009) and market-based arm's-length relationships between investors and firms are hardly visible.

Similarly, although the privatization of some state- and KMT-controlled enterprises in upstream sectors since 1990 has enabled some groups to integrate backwards (Chung 2006), the extent of ownership-based vertical coordination remains relatively limited, especially when contrasted with that of the larger Korean chaebol. Horizontal diversification has, however, grown substantially, with the largest 100 business groups becoming active in 11.51 2-digit SIC industries in 2004, mostly through entering sectors that have become deregulated and where privatized firms became available for acquisition (Chung and Mahmood 2010).

It is worth noting here that the level of unrelated diversification has become more varied between these groups, with the standard deviation of the number of affiliates active in different 2-digit industries rising from 3.12 in 1981 to 7.42 in 2004, often because of differential access to information and support from politicians and senior bureaucrats (Chung 2006). It has also tended to be greater amongst groups with particularly high amounts of family ownership and control, principally because as they expanded into new sectors, they appeared more reluctant to leave declining ones (Chung and Mahmood 2010). There is some evidence that groups based mostly in the newer industries of electronics and ICT tend to diversify into unrelated sectors rather less than longer-established groups originating in other industries, but overall ownership-based horizontal integration is still considerable (Lee and Hsiao 2013).

Alliance-based integration remains limited to relatively short-term partnerships, although the centre-satellite network structure of vertical alliances seems to have become more established with state encouragement (Guerrieri and Pietrobelli 2006; Lin and Chaney 2007). The growing importance of business groups seems to have intensified ownership and directorship linkages within them, at the expense of those between groups (Brookfield 2010), but Lee and Hsiao (2013) indicate the importance of kinship connections between many of the financially dominated groups, and suggest that the groups active in recently deregulated industries, and those where substantial capital resources for new ventures are required, tend to form particularistic alliances cemented through family ties. At least in some areas of Taiwan's economy, then, highly personal alliance-based coordination is quite significant.

Equally, while much inter-firm collaboration and cooperation has been fairly short term and opportunistic in the SME sector (Schak 2000), it has become more formally organized in the newer high-technology industries, often with substantial state support 
and the active participation of business associations (Guerrieri and Pietrobelli 2006; Tung 2001; Tzeng, Beamish, and Chen 2011). Also, the weak anti-trust tradition has allowed a number of overlapping directorships and other forms of connecting firms' activities to become established between companies in the same industry in some sectors, notably plastics, textiles, electrical machinery, iron and steel, and shipping (Brookfield 2010), and oligopolistic structures seem to be more common since democratization. Overall, then, the increasingly dominant role of business groups in Taiwan appears to have led to a more interlinked network of alliances and collaborations, particularly between those based around financial holding-companies, and more formal arrangements for cooperation between companies involved in developing new technologies (Tung 2001; Zhang 2012; Zhang and Whitley 2013).

Turning finally to employment relationships and the organization of authority within firms, labour turnover has traditionally varied considerably between the predominantly Taiwanese-owned SME sector, where it was quite high with frequent job-hopping, and the more stable large-firm state-owned sectors. Since democratization, business-group growth, some SOE privatization, and regulatory reform have reduced these differences, but the relative strength of unions in the SOE sector and their ability to mobilize political support have both limited the extent of privatization compared to Korea and ensured that employment remains somewhat longer term than in the small-firm sector (Lee 2009). Overall, though, despite the expansion of business groups and average firm size, companies remain reluctant to institutionalize long-term organization-specific careers for staff without family or family-like connections with the owners, and employeremployee commitment in the bulk of the economy remains weak.

This relative lack of commitment to investing in, and developing, firm-specific knowledge and long-term careers with particular companies is partly explained by, and reinforces, the widespread centralization of decision-making by family and other members of the 'inner circle' dominating the management of most Taiwanese firms (Chung and Mahmood 2010; Lee and Hsiao 2013). This core group may extend beyond the immediate founder and members of his immediate family to more distant relatives and trusted partners as successful firms grow, and second- or third-generation family members take control (Chung and Luo 2008), but there is little evidence of such changes leading to more collegiate management practices and delegation of authority to middle-managers, let alone to trusting the bulk of the workforce with greater task autonomy and involvement in problem-solving.

This summary of the key characteristics of the dominant business system in contemporary Taiwan indicates that changes to the political and financial systems have resulted in the growth of private-sector coordination of economic activities through diversified business groups. However, continuing, if reduced, state influence over the financial system and ownership of some large enterprises, coupled with a more proactive state role in developing new industries in conjunction with private Taiwanese firms than was typical in the 1960-70s, have limited the decline of the developmental state and led to an expansion of state-big business collaboration and coordination of industrial development, especially in high-technology sectors (Fields 2012; Lee 2009; Thurbon and Weiss 2006). 
In fact, it is arguable that the previous dualist division of the political economy between the large-enterprise upstream sector dominated by state- and KMT-owned companies and the private Taiwanese-owned SME sectors has been superseded by a more integrated system in which business groups constitute the major economic actors, although differences exist between sectors in how much these groups coordinate activities (Zhang and Whitley 2013). However, these groups continue to be largely family owned and controlled, despite some growth in equity-based investment funding, with little evidence of significant change in authority relationships between owners, managers, and most employees, or in labour-turnover rates. The overall expansion of economic coordination within and between sectors represented by the growth of business groups in Taiwan, then, has not been accompanied by much change in prevalent patterns of corporate governance or employment practices.

\section{CONCLUding Remarks}

This discussion of change and continuity in dominant institutions, geo-political contexts, and business-system characteristics in East Asia has highlighted four main points. First, despite the weakening of the strong developmental state, varied liberalization of capital and labour markets, and internationalization of many companies, there is little evidence that dominant business systems in these three political economies are becoming more similar to those in the Anglo-American world, or indeed to each other (Shin and Hamilton 2013). Both the broad system of governing institutions, dominant interest-groups, and patterns of political cooperation and competition on the one hand, and the prevalent form of economic coordination and control on the other hand, still display significant differences between Japan, Korea, and Taiwan, even as their economic interdependence grows. The semi-globalized (Ghemawat 2003) world economy, expansion of democratic politics, and growing influence of transnational governance (Djelic and Quack 2003; Djelic and Sahlin-Andersson 2006) have not resulted in the homogenization of either dominant institutions or business systems along Anglo-American lines, nor have these phenomena generated the same kinds of radical changes. Nationally specific changes in dominant coalitions, patterns of industrialization, and state-business relations in particular geo-political situations continue to exert major, if not dominant, influences on how institutional changes such as democratization take place and affect patterns of economic organization (Walter and Zhang 2012).

Second, while the decline in the cohesion and autonomy of strong developmental states and the reduction of institutional complementarities may in general be expected to reduce the homogeneity and standardization of dominant firm-type and competitive behaviour across sectors and regions as companies become less dependent on government loans and other forms of direct support, and less constrained to follow state priorities, this is unlikely to happen quickly, and often does not apply to all aspects of corporate governance and behaviour. In post-war Japan, for instance, the weakening of the 'iron 
triangle' between LDP, bureaucratic and big-business elites, and the restructuring of the banking system and many keiretsu in the 1990 os and early 2000 s may have led to some diversity of corporate governance and employment policies in different firms and sectors. However, the continuing close involvement of the state in coordinating responses to economic decline and promoting new industries, the continuing importance of business associations in developing and implementing policies and coordinating actions, and the continuing significance of banks in supporting many companies, together with less than radical deregulation of many markets and commitment of key interest groups to established ways of organizing economic activities (Zhang and Whitley 2013), have limited the extent of change to the networked alliance capitalism that remains Japan's prevalent mode of economic coordination and control.

Third, just as the deregulation of capital markets does not always, or even often, lead to an expansion of equity-financed investment, arm's-length relationships between investors and managers, and an active market for corporate control (as shown by these countries), so too the removal of some restrictions on hiring and firing, use of temporary and part-time staff, and similar deregulatory measures need not intensify adversarial employment relationships and a widespread decline in long-term employment commitments. Rather, such measures permit a greater variety of firm behaviours, especially between sectors, as seen in Japan, and can often be combined with considerable employer-employee commitment, albeit with a somewhat shrunken core workforce.

Fourth, as the considerable continuities in many aspects of corporate governance, inter-firm connections, and employment practices amongst leading firms in these political economies indicate, quite substantial changes in dominant institutions and geo-political contexts need not, and often do not, produce equally marked shifts in prevalent business-system characteristics in the short to medium term. This is especially so where other features of the business environment, such as the continuing limited levels of trust in formal institutions and willingness to trust people with whom one does not have family-like relationships in Korea and Taiwan, remain substantially the same. In these cases, such low trust seems to have inhibited owners from delegating more and relying less on personal knowledge and contacts to generate competitive advantages.

As Wong, Wan, and Hsiao (2011) suggest, democratization of political competition does not, per se, automatically lead to greater trust in political institutions and actors, particularly if it fails to reduce corruption and the political favouring of special interests. Indeed, it may increase awareness of such phenomena, as mass media become more independent of the state, and encourage firms to rely more on personal contacts and special favours than on formal rules and sanctions, as arguably has happened in Taiwan (Copper 2009; Wu 2007). Thus, while declining authoritarianism and state domination of the economy may well create opportunities for businesses to pursue a variety of strategies and behaviours, it won't necessarily encourage them to decentralize control and trust formal institutions to manage uncertainty and deviance if personal connections remain key to many sources of competitive advantage, especially in the short to medium term. 


\section{REFERENCES}

Aguilera, R., L. R. Kabbach de Castro, J. H. Lee and J. You (2012). 'Corporate Governance in Emerging Markets'. In G. Morgan and R. Whitley, Eds., Capitalisms and Capitalism in the Twenty-First Century: 319-344. Oxford, Oxford University Press.

Almeida, H., S. Y. Park, M. Subrahmanyam, and D. Wolfenzen (2009). 'The Structure and Formation of Business Groups: Evidence from Korean Chaebols'. National Bureau of Economic Research Working Paper 14983, Cambridge, USA: National Bureau of Economic Research.

Amsden, A. H. (1989). Asia's Next Giant. Oxford, Oxford University Press.

Amable, B. (2003). The Diversity of Modern Capitalism. Oxford, Oxford University Press.

Amable, B. G. Jackson, and H. Miyajima, Eds. (2007). Corporate Governance in Japan. Oxford, Oxford University Press.

Aoki, M. and H. Patrick, Eds. (1994). The Japanese Main Bank System. Oxford, Clarendon.

Aoki, M. and R. Dore, Eds. (1994). The Japanese Firm. Oxford, Oxford University Press.

Bae, K. (1987). Automobile Workers in Korea. Seoul, Seoul National University Press.

Beeson, M. (2009). 'Developmental States in East Asia: A Comparison of the Japanese and Chinese Experiences'. Asian Perspective 33 (2): 5-39.

Boyer, R. (2004). 'New Growth Regimes, But Still Institutional Diversity'. Socio-Economic Review 2: 1-32.

Braithwaite, J. and P. Drahos (200o). Global Business Regulation. Cambridge, Cambridge University Press.

Brookfield, J. (2010). 'The Network Structure of Big Business in Taiwan'. Asia-Pacific Journal of Management 27: 257-279.

Calder, K. E. (1993). Strategic Capitalism: Private Business and Public Purpose in Japanese Industrial Finance, Princeton, Princeton University Press.

Choe, S. and T. Roehl (2007). 'What to Shed and What to Keep: Corporate Transformation in Korean Business Groups.' Long Range Planning 40: 465-487.

Chung, C-N.(2004). 'Institutional Transition and Cultural Inheritance: NetworkCharacteristics and Corporate Control of Business Groups in Taiwan, 1970s-1990s'. International Sociology 19: 25-50.

Chung, C-N. (2006). 'Beyond Guanxi: Network contingencies in Taiwanese business groups'. Organization Studies 27: 461-489.

Chung, C-N. and X. Luo (2008). 'Human Agents, Contexts and Institutional Change: The Decline of Family in the Leadership of Business Groups'. Organization Science 19: 124-142.

Chung, C-N. and I. Mahmood (2010). 'Business Groups in Taiwan'. In A. Colpan, T. Hikino, and J. Lincoln, Eds., Oxford Handbook of Business Groups: 180-209. Oxford, Oxford University Press.

Clark, R. (1979). The Japanese Company. New Haven, Yale University Press.

Colpan, A., T. Hikino, and J. Lincoln, Eds. (2010). Oxford Handbook of Business Groups. Oxford, Oxford University Press.

Copper, J. (2009). 'The Devolution of Taiwan's Democracy during the Chen Shui-bian Era'. Journal of Contemporary China 18: 463-478.

Deyo, F. C. (1989). Beneath the Miracle: Labour Subordination in the New Asian Industrialism. Berkeley: University of California Press.

Deyo, F. C. (2012). 'Reform and Institutional Change in East Asian Labour Markets'. In A. Walter and X. Zhang, Eds., East Asian Capitalism: 91-109. Oxford: Oxford University Press. 
Djelic, M-L. and S. Quack, Eds. (2003). Globalization and Institutions. Cheltenham, Edward Elgar.

Djelic, M-L. and K. Sahlin-Andersson, Eds. (2006). Transnational Governance. Cambridge, Cambridge University Press.

Dore, R. P. (1973). British Factory, Japanese Factory. London, Allen and Unwin.

Dore, R. P. (2007). 'Insider Management and Board Reform'. In M. Aoki, G. Jackson, and H. Miyajima, Eds., Corporate Governance in Japan:370-395. Oxford, Oxford University Press. Evans, P. (1995). Embedded Autonomy. Princeton, Princeton University Press.

Fields, K. (1995). Enterprise and the State in Korea and Taiwan. Ithaca, Cornell University Press.

Fields, K. (2012). 'Not of a Piece: Developmental States, Industrial Policy and Evolving Patterns of Capitalism in Japan, Korea, and Taiwan'. In A. Walter and X. Zhang, Eds., East Asian Capitalism: 46-67. Oxford: Oxford University Press

Friedman, D. (1988). The Misunderstood Miracle. Ithaca, Cornell University Press.

Fruin, M. (1992). The Japanese Enterprise System. Oxford, Oxford University Press.

Fujimoto, T. (1999). The Evolution of a Manufacturing System at Toyota. Oxford, Oxford University Press.

Fujimura, H. (1997). 'New Unionism: Beyond Enterprise Unionism?'. In M. Sako and H. Sato, Eds., Japanese Labour and Management in Transition: 296-314. London, Routledge and Kegan Paul.

Garon, S. (1997). Molding Japanese Minds. Princeton, Princeton University Press.

Gerlach, M. (1992). Alliance Capitalism. Berkeley, University of California Press.

Ghemawat, P. (2003). 'Semi-Globalization and International Business Strategy'. Journal of International Business Studies 34: 138-152.

Gold, T. B. (1986). State and Society in the Taiwan Miracle. Armonk, M.E. Sharpe.

Gray, K. (2011). 'Taiwan and the Politics of Late Development'. Pacific Review 24: 577-599.

Guerrieri, P. and C. Pietrobelli (2006). 'Old and New Forms of Clustering and Production Networks in Changing Technological Regimes: Contrasting Evidence from Taiwan and Italy'. Science, Technology \& Society 11: 9-38.

Hamilton, G. and C-S. Kao (1990). 'The Institutional Foundation of Chinese Business: The Family Firm in Taiwan'. Comparative Social Research 12: 95-112.

Hsieh, M. (2011). 'Similar Opportunities, Different Responses: Explaining the Divergent Patterns of Development between Taiwan and South Korea. International Sociology 26: 364-391.

Inagami, T. and H. Whittaker (2005). The New Community Firm: Employment, Governance and Management Reform in Japan. Cambridge, Cambridge University Press.

Jackson, G. (2007). 'Employment Adjustmeunt and Distributional Conflict in Japanese Firms'. In M. Aoki, G. Jackson, and H. Miyajima, Eds., Corporate Governance in Japan: 282-309. Oxford, Oxford University Press.

Jackson, G. and H. Miyajima (2007). 'Introduction: The Diversity and Change of Corporate Governance in Japan'. In M. Aoki, G. Jackson, and H. Miyajima, Eds., Corporate Governance in Japan: 1-47. Oxford, Oxford University Press.

Janelli, R. L. (1993) Making Capitalism: The Social and Cultural Construction of a South Korean Conglomerate. Stanford, Stanford University Press.

Johnson, C. (1982). MITI and the Japanese Miracle. Stanford, Stanford University Press.

Keizer, A. (2009). 'Transformations In and Outside the Internal Labour Market: Institutional Change and Continuity in Japanese Employment Practices'. International Journal of Human Resource Management 20: 1521-1535.

Keizer, A. (2011). 'Flexibility in Japanese Internal Labour Markets'. Asia-Pacific Journal of Management 28: 573-594. 
Kikutani, T., H. Itoh, and O. Hayashida (2007). 'Business Portfolio Restructuring of Japanese Firms in the 199os'. In M. Aoki, G. Jackson, and H. Miyajima, Eds., Corporate Governance in Japan: 227-256. Oxford, Oxford University Press.

Kim, C. S. (1992). The Culture of Korean Industry. Tucson: University of Arizona Press.

Kim, D-O. and J. Bae (2005). 'Workplace Innovation, Employment Relations, and HRM: Two Electronics Companies in South Korea. International Journal of Human Resource Management 16: 1277-1302.

Kim, E. M. (1997). Big Business, Big State: Collusion and Conflict in South Korean Development 1960-1990. Albany, State University of New York Press.

Kim, H. (2010). 'Business Groups in Korea'. In A. Colpan. T. Hikino, and J. Lincoln, Eds., Oxford Handbook of Business Groups: 157-179. Oxford, Oxford University Press.

Kim, H. R. Hoskisson, L. Tihanyi, and J. Hong (2004). 'The Evolution and Restructuring of Diversified Business Groups in Emerging Markets: The lessons from chaebol in Korea'. Asia-Pacific Journal of Management 21: 25-48.

King, A. Y. C. (1996). 'State Confucianism and its Transformation: The Restructuring of the State-Society Relation in Taiwan'. In W-M. Tu, Ed., Confucian Traditions in East-Asian Modernity: 228-243. Cambridge: Harvard University Press.

Koike, K. (1987). 'Human Resource Development and Labour Management Relations'. In K. Yamamura and Y. Yasuba, Eds., The Political Economy of Japan I: 289-330. Stanford, Stanford University Press.

Kong, T. Y. (2006). 'Globalization and Labour-Market Reform: Patterns of Response in Northeast Asia.' British Journal of Political Science 36: 359-383.

Laurence, H. (2001). Money Rules. Ithaca, Cornell University Press.

Lechevalier, S. (2007). 'The Diversity of Capitalism and Heterogeneity of Firms: A Case Study of Japan during the Lost Decade. Evolutionary and Institutional Economic Review 4: 113-142.

Lee, K., S. Rho, and S. Kim (2007). 'Creativity-Innovation Cycle for Organizational Exploration and Exploitation: Lessons from Neowitz, a Korean Internet Company'. Long Range Planning 40: $505-523$.

Lee, Y. (2009). 'Divergent Outcomes of Labor-Reform Politics in Democratized Korea and Taiwan'. Studies in Comparative International Development 44: 47-70.

Lee, Z-R. and H-H.M. Hsiao (2013). 'Taiwan: SME-Oriented Capitalism in Transition '. In M. A. Witt and G. Redding, Eds., Oxford Handbook of Asian Business Systems. Oxford, Oxford University Press.

Lin, K-H. and I. Chaney (2007). 'The Influence of Domestic Inter-Firm Networks on the Internationalization Process of Taiwanese SMEs'. Asia-Pacific Business Review 13: 565-583.

Lincoln, J. and M. Gerlach (2004). Japan's Network Economy. Cambridge, Cambridge University Press.

Lincoln, J. and M. Shimotani (2010). 'Business Networks in Post-War Japan: Whither the Keiretsu?' In A. Colpan, T. Hikino, and J. Lincoln, Eds., Oxford Handbook of Business Groups: 127-156. Oxford, Oxford University Press.

MacDuffie, J. P. and S. Helper (2006). 'Collaboration in Supply Chains: With and Without Trust'. In C. Heckscher and P. Adler, Eds., The Firm as a Collaborative Community: 417-466. Oxford, Oxford University Press.

Matsumoto, M. (2002). 'Political Democratization and KMT Party-Owned Enterprises in Taiwan'. Developing Economies XL: 359-380.

Matsuura, K., M. Pollitt, R. Takada, and S. Tanaka (2004). 'Institutional Restructuring in the Japanese Economy since 1985'. In J. Perraton and B. Clift, Eds., Where Are National Capitalisms Now? 133-153. Basingstoke: Palgrave Macmillan. 
Miyajima, H. and F. Kuroki (2007). 'The Unwinding of Cross-shareholding in Japan'. In M. Aoki, G. Jackson, and H. Miyajima, Eds. Corporate Governance in Japan: 79-124. Oxford, Oxford University Press.

Mosk, C. (1995). Competition and Cooperation in Japanese Labour Markets. Basingstoke, Macmillan.

Nakamura, K. (1997). 'Worker Participation: Collective Bargaining and Joint Consultation'. In M. Sako and H. Sato, Eds., Japanese Labour and Management in Transition: 280-295. London, Routledge.

Nakamura, K. (2011). 'Adoption and Policy Implications of Japan's New Corporate Governance Practices after the Reform'. Asia-Pacific Journal of Management 28: 187-213.

Numazaki, I. (1997). 'The Laoban-Led Development of Business Enterprises in Taiwan: An Analysis of Chinese Entrepreneurship'. Developing Economies XXXV: 440-457.

Numazaki, I. (2000). 'Chinese Business Enterprise as Inter-Family Partnership: A Comparison with the Japanese Case'. In K. B. Chan, Ed., Chinese Business Networks: State, Economy, and Culture: 152-175. Singapore, Pearson Education Asia.

Orrù, M., N. Biggart, and G. Hamilton (1997). The Economic Organization of East Asian Capitalism. Thousand Oaks: Sage.

Park, C. and S. Kim (2008). 'Corporate Governance, Regulatory Changes, and Corporate Restructuring in Korea, 1933-2004'. Journal of World Business 43: 66-84.

Peng, I. and J. Wong (2008). 'Institutions and Institutional Purpose: Continuity and Change in East Asian Social Policy'. Politics and Society 36(1): 61-88.

Rohlen, T. P. (1974). For Harmony and Strength. Berkeley, University of California Press.

Samuels, R. J. (1987). The Business of the Japanese State. Ithaca, Cornell University Press.

Sako, M. (2006). Shifting Boundaries of the Firm. Oxford, Oxford University Press.

Sako, M. and M. Kotosaka (2012). 'Continuity and Change in the Japanese Economy: Evidence of Institutional Interactions in Financial and Labour Markets'. In A. Walter and X. Zhang, Eds., East Asian Capitalism: 132. Oxford, Oxford University Press.

Schak, D. (2000). 'Networks and Their Uses in Taiwanese Society'. In C. K. Bun, Ed., Chinese Business Networks: 112-128. Singapore, Prentice-Hall.

Schmidt, V. A. (2002). The Futures of European Capitalism. Oxford, Oxford University Press.

Shieh, G. S. (1992). 'Boss' Island: The Subcontracting Network and Micro-Entrepreneurship in Taiwan's Development. New York, Peter Lang.

Shin, S. and G. Hamilton (2013). '*Beyond Production: Changing Dynamics of Asian Business Groups foxfordhb-9780199654925-016]*'. In M. A. Witt and G. Redding, Eds., Oxford Handbook of Asian Business Systems. Oxford, Oxford University Press.

Shinoda, T. (1997). 'Rengo and Policy Participation: Japanese-Style Neo-Corporatism?'. In M. Sako and H. Sato, Eds., Japanese Labour and Management in Transition: 187-214. London, Routledge.

Silin, R.H. (1976).Leadership and Values: The Organization of Large-Scale Taiwanese Enterprises. Cambridge, Harvard University Press.

Song, J. (2012). 'Economic Distress, Labor-Market Reforms and Dualism in Japan and Korea'. Governance 25: 415-438.

Sturgeon, T. (2006). 'Modular Production's Impact on Japan's Electronics Industry'. In H. Whittaker and R. Cole, Eds., Recoveringfrom Success: 47-69. Oxford, Oxford University Press.

Sugeno, K. and Y. Suwa (1997). 'Labour-Law Issues in a Changing Labour Market: In Search of a New Support System'. In M. Sako and H. Sato, Eds., Japanese Labour and Management in Transition: 53-78. London, Routledge. 
Thurbon, E. (2001). 'Two Paths to Financial Liberalization: South Korea and Taiwan'. Pacific Review 14: 241-267.

Thurbon, E. and L. Weiss (2006). 'Investing in Openness: The Evolution of FDI Strategy in South Korea and Taiwan'. New Political Economy 11(1): 1-22.

Tung, A-C. (2001). 'Taiwan's Semiconductor Industry'. Review of Development Economics 5: $266-288$.

Tzeng, C-H., P. Beamish, and S-F. Chen (2011). 'Institutions and Entrepreneurship Development: High-Technology Indigenous Firms in China and Taiwan'. Asia-Pacific Journal of Management 28: 453-481.

Wade, R. (1990). Governing the Market: Economic Theory and the Role of Government in East Asian Industrialization. Princeton, Princeton University Press.

Walter, A. and X. Zhang, Eds. (2012). East Asian Capitalism. Oxford, Oxford University Press.

Weiss, L. (2004). 'Developmental States Before and After the Asian Crisis'. In J. Perraton and B. Clift, Eds., Where are National Capitalisms Now? 154-168. Basingstoke, Palgrave Macmillan. (2010). 'The State in the Economy: Neo-Liberal or Neo-Activist?'. In G. Morgan, J. Campbell, C. Crouch, O. Pedersen, and R. Whitley, Eds., Oxford Handbook of Comparative Institutional Analysis: 183-210. Oxford, Oxford University Press.

Whitley, R. (1992). Business Systems in East Asia. Thousand Oaks, Sage.

— (1999). Divergent Capitalisms. Oxford, Oxford University Press.

- (2005). 'How National are Business Systems?'. In G. Morgan, R. Whitley, and E. Moen, Eds., Changing Capitalisms? 190-231. Oxford, Oxford University Press.

- (2007). Business Systems and Organizational Capabilities. Oxford, Oxford University Press.

Witt, M. A. (2013a). 'Japan: Coordinated Capitalism Between Institutional Change and Structural Inertia.' In M.A. Witt and G. Redding, Eds., Oxford Handbook of Asian Business Systems. Oxford, Oxford University Press.

— (2013b). ' South Korea: Plutocratic State-Led Capitalism Reconfiguring'. In M. A. Witt and G. Redding, Eds., Oxford Handbook of Asian Business Systems. Oxford, Oxford University Press.

Wong, T., P-S. Wan, and H-H.M. Hsiao (2011). 'The Bases of Political Trust in Six Asian Societies'. International Political Science Review 32: 263-281.

Woo, J-E. (1991). Race to the Swift. New York, Columbia University Press.

Wu, Y. (2007). 'Taiwan's Developmental State'. Asian Survey 47: 977-1001.

Zhang, X. (2009). 'From Banks to Markets'. Review of International Political Economy 16:382-408.

- (2012). 'Dominant Coalitions and Capital-Market Changes in Northeast Asia'. In A. Walter and X. Zhang, Eds., East Asian Capitalism: 223-243. Oxford, Oxford University Press.

Zhang, X. and R. Whitley (2013). 'Changing Macro-Structural Varieties of East Asian Capitalism' Socio-Economic Review 11. 301-336. 